\title{
Bevacizumab significantly increases the risks of hypertension and proteinuria in cancer patients: A systematic review and comprehensive meta-analysis
}

\author{
Tingting Zhao ${ }^{1, *}$, Xiaonan Wang ${ }^{1, *}$, Tingting $X \mathbf{u}^{1, *}$, Xiaodong $\mathrm{Xu}^{1}$ and Zhihong Liu ${ }^{1}$ \\ ${ }^{1}$ National Clinical Research Center of Kidney Diseases, Jinling Hospital, Nanjing University School of Medicine, Nanjing, \\ Jiangsu, 210002, China \\ *These authors contributed equally to this work \\ Correspondence to: Zhi-Hong Liu, email: Liuzhihong@nju.edu.cn
}

Keywords: bevacizumab, chemotherapy, hypertension, proteinuria, cancer

Received: December 07, $2016 \quad$ Accepted: February 20, $2017 \quad$ Published: May 23, 2017

Copyright: Zhao et al. This is an open-access article distributed under the terms of the Creative Commons Attribution License 3.0 (CC BY 3.0), which permits unrestricted use, distribution, and reproduction in any medium, provided the original author and source are credited.

\section{ABSTRACT}

Published data regarding the overall risks and incidence of hypertension and proteinuria associated with bevacizumab were still unclear. To quantify the precise risks and incidence, we performed this comprehensive meta-analysis of 72 published clinical trials including 21902 cases and 20608 controls. The overall incidence, risk ratios (RRs), and $95 \%$ confidence intervals (95\% CIs) were calculated using a fixed or randomeffect model based on the heterogeneity. The incidence of all-grade and high-grade hypertension were $25.3 \%$ (95\% CI: $21.5 \%-29.5 \%)$ and $8.2 \%(95 \%$ CI: $7 \%-9.8 \%$ ) for patients treated with bevacizumab. And the incidence of all-grade and high-grade proteinuria were $18 \%$ (95\% CI: $11.7 \%-26.6 \%$ ) and $2.4 \%(95 \%$ CI: $1.8 \%-3.2 \%)$, respectively. Compared with controls, bevacizumab significantly increased the risks of all-grade (RR: 3.595, 95\% CI: 2.952-4.378) and high-grade hypertension (RR: 5.173, 95\% CI: 4.188-6.390). Obviously increased risks of all-grade (RR: 3.369, 95\% CI: 2.492-4.556) and high-grade proteinuria (RR: 5.494, 95\% CI: 3.991-7.564) were also observed. In the subgroup analysis, the risks of hypertension and proteinuria may significantly vary with bevacizumab dosage, cancer types and concomitant drugs. Whereas, no obvious difference were discovered when stratified based on phase of trials, age of patients, treatment line and duration. So, close monitor and effective management were highly recommended for the safe use of bevacizumab.

\section{INTRODUCTION}

Tumor angiogenesis mediated by vascular endothelial growth factor (VEGF) plays a pivotal role in the growth, invasion, and metastasis of tumor [1-3]. So, the VEGF signaling pathway has been a major focus in current cancer treatment $[3,4]$. Bevacizumab (Avastin, Genentech, South San Francisco, CA), a recombinant humanized monoclonal antibody against VEGF, has been widely used in the treatment of various cancers, including colorectal cancer, breast cancer, lung cancer, renal cell cancer, ovarian cancer, pancreatic cancer, gastric cancer, glioblastoma and so on [5-18].

Similar to other angiogenesis inhibitor, bevacizumab may also lead to substantial adverse effects, such as nausea, fatigue, diarrhea, hemorrhage, thrombosis, wounding-healing complications and renal toxicities [19]. Hypertension and proteinuria are the dominant adverse effects for renal toxicities [20]. Previous studies have demonstrated that the RRs of all-grade proteinuria for patients administered bevacizumab at $2.5 \mathrm{mg}$ and $5 \mathrm{mg} / \mathrm{kg} /$ week were 1.4 (95\% CI: $1.1-1.7)$ and 2.2 (95\% CI: 1.6$2.9)$, respectively, and the RRs of all-grade hypertension for different dosage were 3.0 (95\% CI: 2.2-4.2) and 7.5 (95\% CI: 4.2-13.4), respectively [20].

High-grade hypertension and proteinuria (grade 3-4), especially hypertensive crisis and nephrotic syndrome, may cause obvious cardiovascular damage and renal failure. Those life-threatening consequence would limit the dose of bevacizumab, thereby reducing 
its efficacy [21]. The incidence of high-grade proteinuria for patients accepted bevacizumab varied considerably, ranging from $0.3 \%$ in a breast cancer study to $15.5 \%$ in an renal cell cancer study $[8,22]$. The similar variation also exited for the incidence of high-grade hypertension, ranging from $0.7 \%$ in a colorectal cancer study to $60 \%$ in an lung cancer study $[23,24]$. Due to the limited number of patients available in each clinical trial and a great deal of large sample size randomized controlled trials (RCTs) have been carried out, the power of the previous meta-analysis to fully elucidate the risks and incidence of proteinuria and hypertension with bevacizumab was immature [20, 21, 25]. Therefore we performed this systematic meta-analysis including all available published RCTs focused on different subgroups to estimate the overall risks and incidence of hypertension and proteinuria associated with bevacizumab.

\section{RESULTS}

\section{Search results}

Over 1052 clinical literatures relevant to the search terms were obtained. After selection by title screening, clinical data quality check, and abstract review, a total of 72 eligible studies were identified for analysis (Figure 1), which contained 21902 cases and 20608 controls. All of the patients enrolled had adequate hepatic, renal, and hematologic function, and the baseline Eastern Cooperative Oncology Group (ECOG) status for most of the patients was between 0 and 1. These trials included 23 phase II and 49 phase III studies, and the characteristics of selected studies were summarized in Supplementary Table 1.

All of the studies included twenty-one colorectal cancer [5, 24, 26-45], fifteen breast cancer [6, 22, 46-58], fifteen lung cancer [7, 23, 59-71], three renal cell cancer $[8,72,73]$, two pancreatic cancer $[10,74]$, four ovarian cancer [9, 75-77], two gastric cancer [11, 78], two glioblastoma [12, 79], two lymphoma [13, 80], two melanoma [14, 81], one malignant mesothelioma [15], one prostate cancer [16], one cervical cancer [17] and one leiomyosarcoma [18]. The level of hypertension and proteinuria were assessed and recorded according to CTCAE version 1, 2, 3 or 4. Version 1 was used in 2 trials, version 2 was used in 11 trials, version 3 was used in 39 trials, Version 4 was used in 6 trials, and the remainder 14 trials did not specify the version. In addition, 24 trials were treated with low-dose $(2.5 \mathrm{mg} / \mathrm{kg} /$ week $)$ and 42 trials were treated with

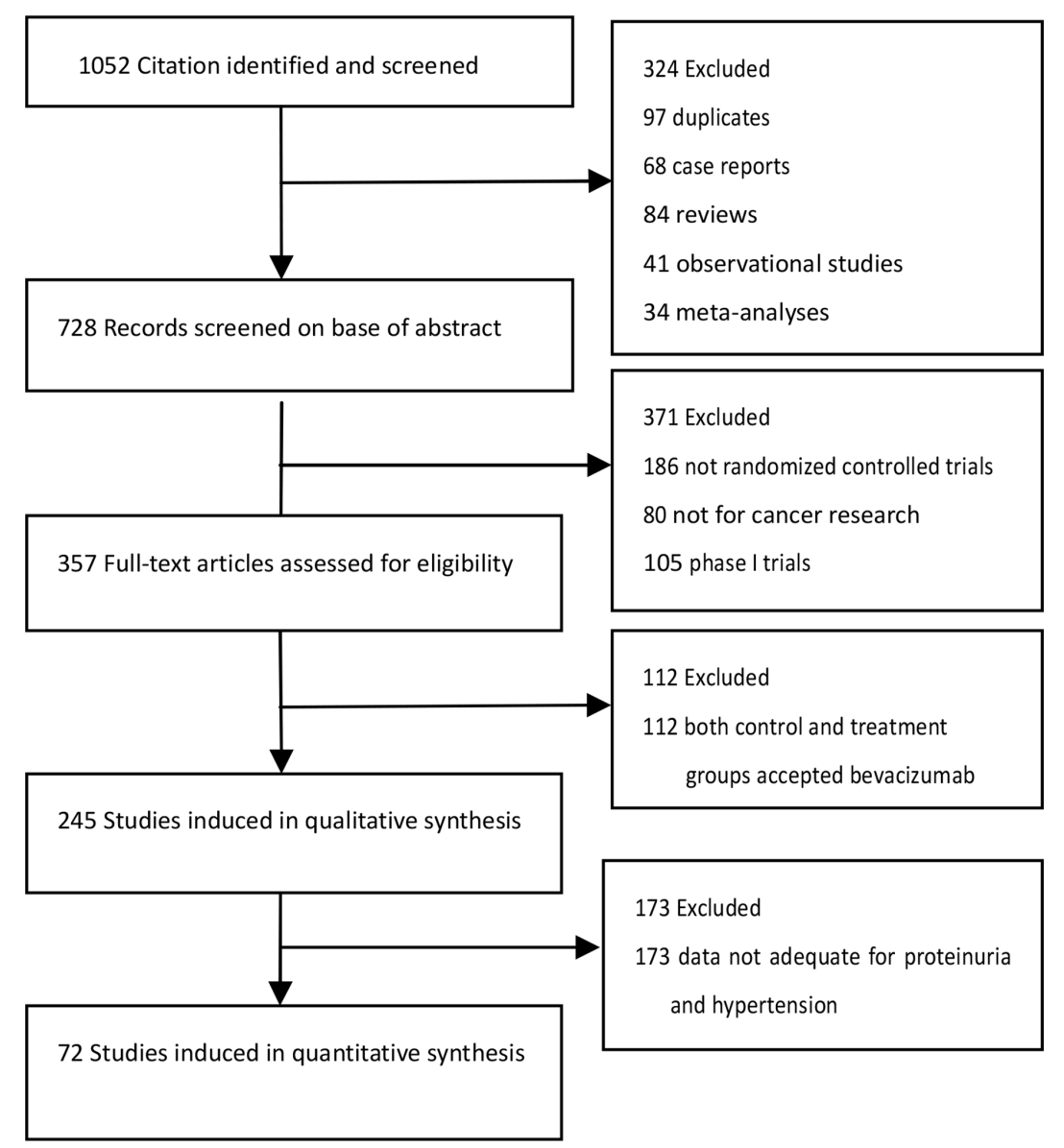

Figure 1: Selection process for randomized-controlled trials (RCTs) included in the meta-analysis. 
high-dose ( $5 \mathrm{mg} / \mathrm{kg} /$ week) bevacizumab. Other six three-arm studies were also included: two arms of different dosage levels of bevacizumab and one arm of control [38, 53, 62, $64,67,73]$ (Supplementary Table 1). The quality of all the trials was acceptable.

\section{Hypertension}

\section{High-grade hypertension}

A total of 39019 patients from 66 RCTs with available high-grade hypertension data were included for analysis [5-18, 22-24, 26-30, 32-39, 41-43, 45-57, 59-68, 70-79, 81]. Our results demonstrated that the summary event rate was 8.2\% (95\% CI: 7\%-9.8\%, Supplementary Table 2) in a random-effect model for the patients administered with bevacizumab. The RR was 5.173 (95\% CI: 4.188-6.390) compared with controls, indicating an obviously increased risk of high-grade hypertension with bevacizumab. Further stratified analysis based on bevacizumab dosage, tumor types, and phases of trials, treatment lines, concomitant drugs, age of patients and treatment duration were conducted to explore the real relationships between the increased risks and various clinical characters. In the stratified analysis by the dosage of bevacizumab, the RR of high-grade hypertension for low-dose bevacizumab was 3.875 (95\% CI: 2.645-5.675), and the RR for high-dose was 6.020 (95\% CI: 4.661-7.775) as shown in Figure 2A and $2 \mathrm{~B}$. A significant difference $(P=0.033)$ was existed between the low and high dosage, suggesting that the risk may be dose-dependent. In the subgroup analysis by caner types, although obviously increased risks were observed in all types, the RR significantly varied $(P=$ 0.039), with the highest RR for rental cancer $13.074(95 \%$ CI: 2.631-64.96) and the lowest RR for pancreatic cancer 3.472 (95\% CI: 1.804-6.679) (Supplementary Table 2). We also conducted subgroup analysis base on treatment line and phase of trials. No significant difference was observed between patients in phase II and phase III trials (RR: 3.387 VS. 5.874, $P=0.155$ ), which was similar to the result between per-treated patients and native-treated patients (RR: 5.182 VS. 5.086, $P=0.728$, Supplementary Table 2). In addition, subgroup analysis stratified based on concomitant drugs was also performed, the incidence of high-grade hypertension varied from $6.1 \%$ to $10.9 \%$. But, no significant difference was observed $(\mathrm{P}=0.808)$. Besides, in the subgroup analysis by the length of bevacizumab treatment duration, patients with long treatment had the RR of 7.045 (95\% CI: 4.556-10.894), and others in short treatment had the RR of 4.192 (95\% CI: 2.958-5.942). But, no obvious difference was obtained between the short and long treatment ( $P=0.359$, Supplementary Table 2). Finally, subgroup analysis base on the age of patients was also conducted, but no significant difference for the RR was observed between patients $<60$ and $\geq 60$ years (RR: 5.774 VS. 3.690, $P=0.08$ ).

\section{All -grade hypertension}

A total of 19057 patients from 39 RCTs with available all-grade hypertension data were included for the analysis $[5,7,8,12,14,18,22,23,26,30-32$, $37-41,44-47,49,50,52,55,59,60,62-66,69,72-74$, $76,79,80]$. For the patients accepted bevacizumab, our result demonstrated that the incidence was $25.3 \%(95 \%$ CI: $21.5 \%-29.5 \%$, Supplementary Table 3) calculated in a random-effect model. The RR was 3.59 (95\% CI: 2.952-4.378) compared with controls, indicating an obviously increased risk for all-grade hypertension with bevacizumab. In the subgroup analysis by the dosage of bevacizumab, the RR for low-dose bevacizumab was 2.969 (95\% CI: 2.311-3.815) and for high-dose was 4.068 (95\% CI: 3.067-5.397) as shown in Figure 3A. Whereas, no significant difference was obtained between the low and high dosage of bevacizumab $(P=0.991)$. In the stratified analysis by caner types, obviously increased risks were observed in all cancer types, with the highest RR for breast cancer 5.119 (95\% CI: 2.415-10.849) and the lowest for pancreatic cancer 2.238 (95\% CI: 1.455- 3.342). But there were no significant difference between various cancer types $(P=0.943$, Supplementary Table 3$)$. We also conducted subgroup analysis base on treatment line and phase of trials. No significant difference was observed between patients in phase II and phase III trials (RR: 3.134 VS. $3.795, P=0.438$ ), which was similar to the result between per-treated patients and native-treated patients (RR: 3.662 VS. 3.219, $\mathrm{P}=0.671$ ). In addition, subgroup analysis stratified based on concomitant drugs was also performed, with the highest RR 7.686 (95\% CI: 0.537$109.921)$ in conjunction with irinotecan and the lowest RR 2.350 (95\% CI: 1.645-3.358) used in combination with gemcitabine (Supplementary Table 3). But, no significant different was observed between various concomitant drugs $(P=0.126)$. Besides, in the stratified analysis by the length of treatment duration, patients with long treatment had the RR of 4.173 (95\% CI: 2.641-6.592), and others in short treatment had the RR of 5.496 (95\% CI: 3.690-8.187). But, no obvious difference was obtained between the short and long treatment $(P=0.934$, Supplementary Table 3$)$. Finally, subgroup analysis base on the age of patients was also conducted, but no significant difference was observed for the RR of all-grade hypertension between patients $<60$ and $\geq 60$ years (RR: 2.848 VS. 3.163, $P=0.225$ ).

\section{Proteinuria}

\section{High-grade proteinuria}

A total of 29906 patients from 45 RCTs with available high-grade proteinuria data were included for the analysis [7-13, 15-17, 22, 23, 26, 28-30, 32, 33, 35, 37, 39, 41-43, 45, 48, 49, 51, 53-56, $63-65,67,68,71-79]$. Among the patients received 
A RR of high-grade hypertension with bevacizumab $2.5 \mathrm{mg} / \mathbf{k g} /$ week

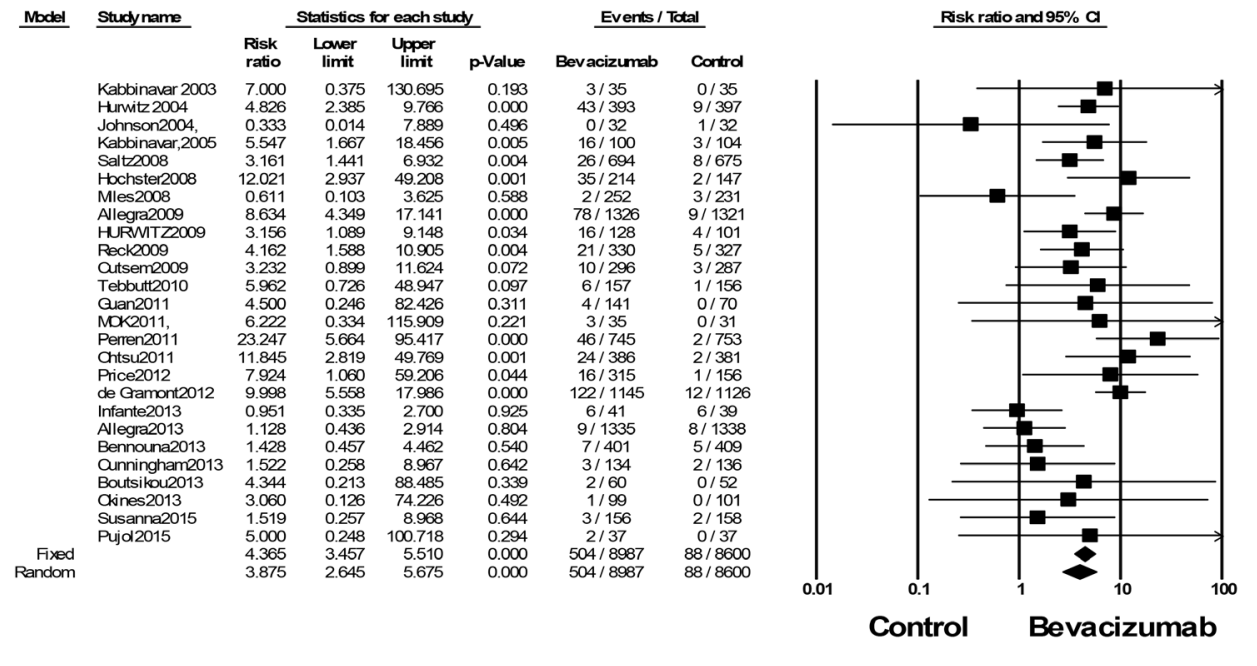

meta analysis

\section{B RR of high-grade hypertension with bevacizumab $5 \mathrm{mg} / \mathrm{kg} /$ week}

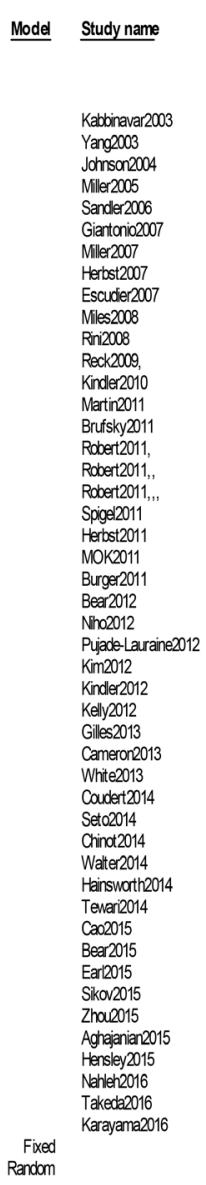

\begin{tabular}{|c|c|c|c|c|c|}
\hline \multicolumn{4}{|c|}{ Statistios for each study } & \multicolumn{2}{|c|}{ Events / Total } \\
\hline iskk & $\begin{array}{l}\text { Lower } \\
\text { limit }\end{array}$ & $\begin{array}{l}\text { Upper } \\
\text { limit }\end{array}$ & $\mathrm{p}$-Value & Bevacizumab & Cont \\
\hline .54 & 1.113 & 308.896 & 0.042 & $8 / 32$ & $0 / 35$ \\
\hline 17.425 & 1.040 & 291.960 & 0.047 & 139 & $0 / 40$ \\
\hline 1.882 & 0.179 & 19.766 & 0.598 & $2 / 34$ & $1 / 32$ \\
\hline 38.493 & 5.342 & 277.400 & 0.000 & $41 / 229$ & $1 / 215$ \\
\hline 10.304 & 3. 168 & 33.512 & 0.000 & $30 / 427$ & $3 / 440$ \\
\hline 3.575 & 1.346 & 9.498 & 11 & $18 / 287$ & | 285 \\
\hline 103.342 & 6.407 & 1666.794 & 01 & $54 / 365$ & $0 / 346$ \\
\hline 5.375 & 0.206 & 108.575 & 3 & $2 / 39$ & $0 / 42$ \\
\hline 4.961 & 1.109 & 2205 & 36 & $11 / 337$ & 2130 \\
\hline 3.429 & 0.969 & 121 & & $1 / 247$ & 2001 \\
\hline 5.736 & 4.673 & 1227.414 & & $39 / 362$ & | 347 \\
\hline 5.566 & 2.176 & 14.237 & & $28 / 329$ & 132 \\
\hline 3.560 & 1.603 & & & $30 / 277$ & 120 \\
\hline 6.490 & 0.815 & 51.70 & & $7 / 96$ & 189 \\
\hline 19.784 & 2739 & 142891 & & $41 / 458$ & 22 \\
\hline 10.199 & 2.492 & 41.7 & & $1 / 404$ & 100 \\
\hline 4.522 & 1.070 & 19. & & $18 / 203$ & 10 \\
\hline 21.540 & 1.320 & 351.53 & & $22 / 210$ & 10 \\
\hline 1.382 & 0.241 & 7.913 & & $3 / 5$ & $4 t$ \\
\hline 3.750 & 1.259 & & & $15 / 313$ & $4 / 313$ \\
\hline & 0.354 & 122.50 & & 31 & $0 / 31$ \\
\hline 3.195 & 2314 & 46 & & $139 / 608$ & $43 / 6$ \\
\hline 10.852 & 4.739 & & & 5 & $6 / 59$ \\
\hline 13.275 & 0.803 & 219.4 & & $13 /$ & $/ 58$ \\
\hline 6.573 & 1.505 & & & & $2 / 18$ \\
\hline 5.347 & 0.300 & 95. & 54 & $5 / 1$ & $0 / 69$ \\
\hline 2.652 & 1.3 & & & & 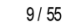 \\
\hline & 23 & & & & $7 / 50$ \\
\hline 23.953 & 3.27 & 175.1 & & 251 & $1 / 20$ \\
\hline 16.776 & & & & & $5 / 12$ \\
\hline 17.000 & 1.008 & 286.818 & & 81 & $0 / 50$ \\
\hline 0.181 & & & & & . \\
\hline 5.775 & 28 & & & 451 & 011 \\
\hline 5.076 & & & & & $10 / 4$ \\
\hline 4.128 & 1.2 & & & & 0 \\
\hline 7.467 & 0.4 & & & & 131 \\
\hline 13.439 & 4. & & & $54 / 220$ & 4 \\
\hline 2.369 & 0.7 & & & & . \\
\hline 31.104 & 7.64 & 126.575 & & 621 & \\
\hline 1.3 & 0.47 & & & & $a^{2}$ \\
\hline 20.628 & & 347.7 & & & \\
\hline 6.7 & 0.835 & & & & $1 / 13$ \\
\hline 21.225 & & & & $45 / 247$ & 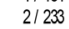 \\
\hline 8.830 & 0.4 & 159.9 & & & \\
\hline 2.702 & 0.719 & & & $7 / 9$ & 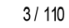 \\
\hline 3.0 & 0.323 & & & & \\
\hline 19.1 & 1. 132 & 324.558 & & $7 / 35$ & \\
\hline 4.974 & 4.2 & 5.8 & & $1173 / 11184$ & \\
\hline $0 x$ & 4.601 & 7.775 & 0.000 & $1173 / 11184$ & \\
\hline
\end{tabular}

Risk ratio and $95 \% \mathrm{C}$

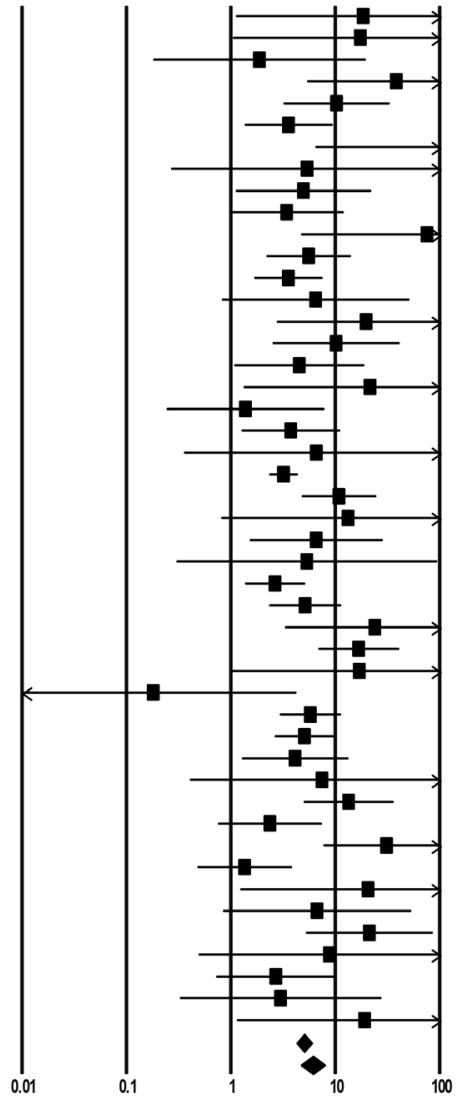

Control Bevacizumab

meta analysis

Figure 2: RRs of high-grade hypertension for cancer patients who received (A) low-dose and (B) high-dose bevacizumab compared with controls. 


\section{A RR of all-grade hypertension with bevacizumab 2.5 and $5 \mathrm{mg} / \mathrm{kg} /$ week}

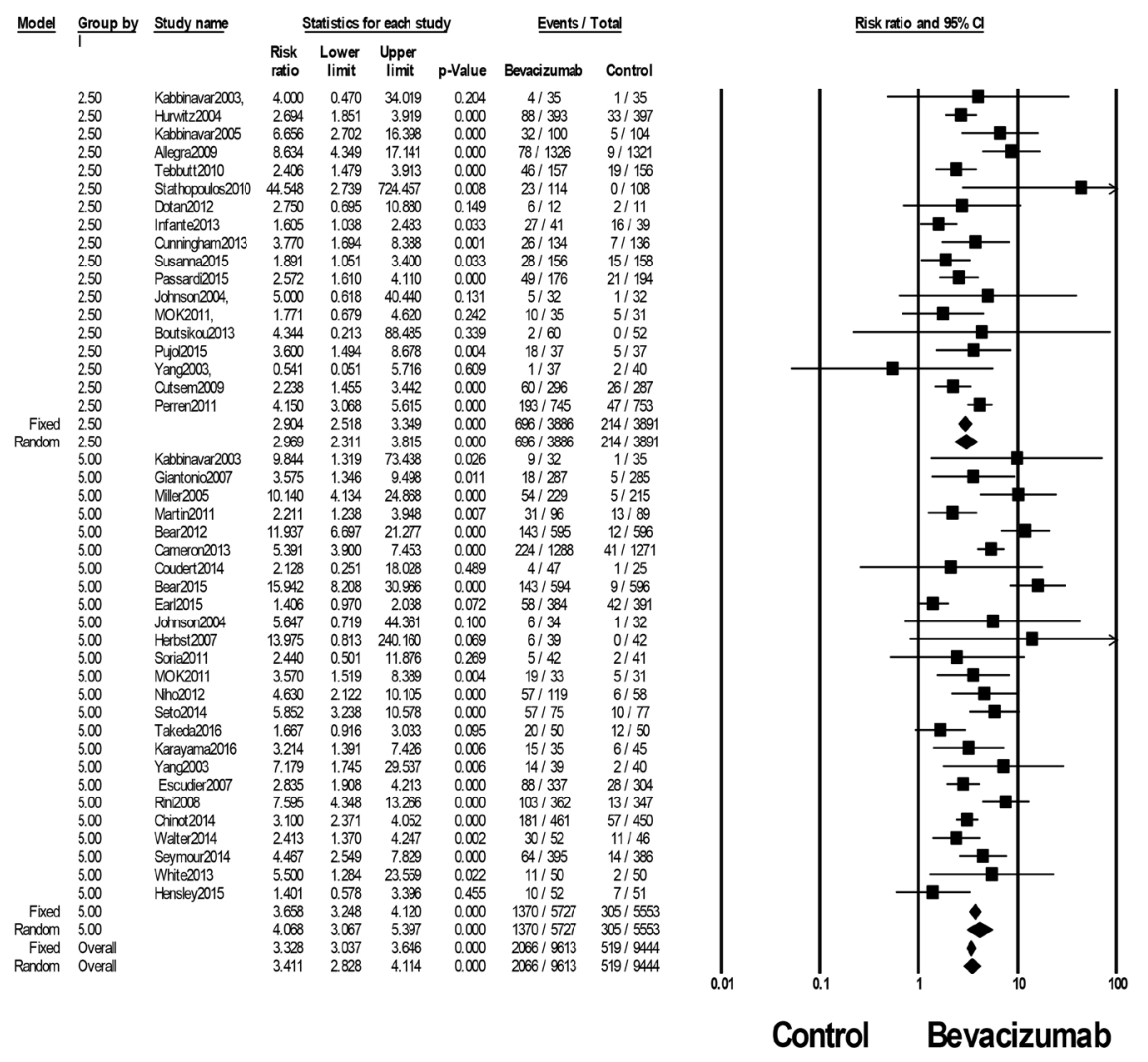

meta analysis

\section{B RR of all-grade proeinuria with bevacizumab 2.5 and $5 \mathrm{mg} / \mathrm{kg} / \mathrm{week}$}

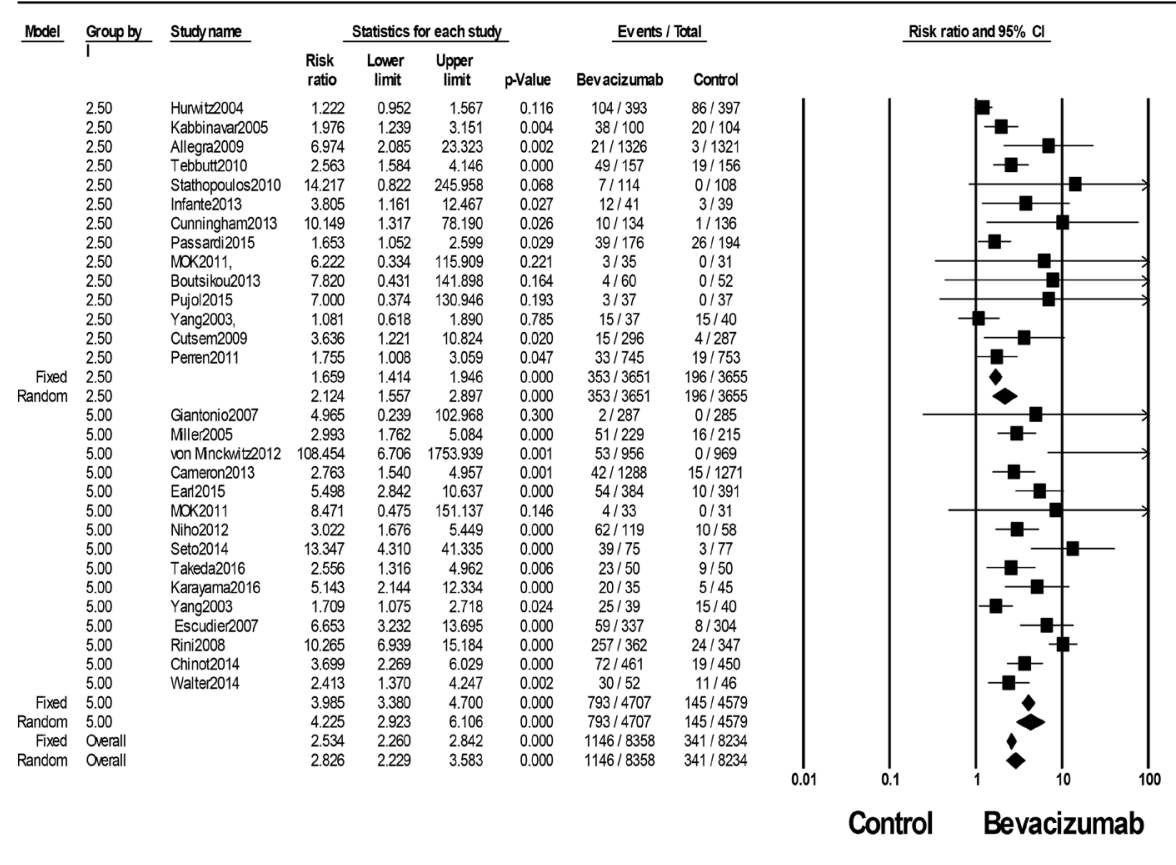

meta analysis

Figure 3: RRs of (A) all-grade hypertension and (B) all-grade proteinuria for cancer patients who received low-dose and high-dose bevacizumab compared with controls. 
bevacizumab, our results demonstrated that the incidence was $2.4 \%$ (95\% CI: $1.8 \%-3.2 \%$ ) calculated in a randomeffect model (Supplementary Table 2). For trials excluding rental cancer, the summary incidence was $2.2 \%$ (95\% CI: $1.7 \%-2.8 \%$ ), suggesting that no significant difference was discovered with and without rental cancer $(P=0.427)$. Compared with controls, the RR for high-grade proteinuria was 5.494 (95\% CI: 3.991-7.564), indicating an obviously increased risk with bevacizumab. In the stratified analysis by the dosage, the incidence of high-grade proteinuria with low-dose bevacizumab was $1.4 \%$ (95\% CI: $0.9 \%-2.1 \%)$, and the incidence of high-dose was 3.2\% (95\% CI: $2.3 \%-4.4 \%$ ) as shown in Figure 4A and 4B. A significant difference $(P=0.012)$ was existed between the low and high dosages of bevacizumab, suggesting that the incidence may be dose-dependent. In the subgroup analysis by caner types, the RR significantly varied $(P=$ 0.008 , Supplementary Table 2), with the highest RR for rental cancer 22.786 (95\% CI: 6.347-81.804) and the lowest for gastric cancer 3.933 (95\% CI: 0.437-35.412). Stratified analysis base on treatment line and phase of trials, no significant difference was observed for the RR between patients in phase II and phase III trials (RR: 3.181 VS. 6.206, $P=0.076$ ), which was similar to the result between per-treated patients and native-treated patients (RR: 5.351 VS. 6.282, $P=0.977$, Supplementary Table 2). In addition, subgroup analysis stratified based on concomitant drugs was also performed and the RRs significantly varied $(P<0.001)$. The highest RR was existed when in conjunction with interferonalfa 48.931 (95\% CI: 9.763-245.31) and the lowest was observed when used in combination with irinotecan 1.704 (95\% CI: 0.474-6.128). Besides, we did subgroup analysis according to the length of bevacizumab treatment duration. Patients with long treatment had RR of 5.786 (95\% CI: 2.746-12.189), and others in short treatment had RR of 5.784 (95\% CI: 3.160-10.588). But, no obvious difference was obtained between the short and long time treatment $(P=0.496$, Supplementary Table 2$)$. Finally, subgroup analysis base on the age of patients was also conducted, but no significant difference was observed for the RR of high-grade proteinuria between patients $<60$ and $\geq 60$ years (RR: 5.618 VS. 4.401, $P=0.606$ ).

\section{All -grade proteinuria}

A total of 16592 patients from 27 RCTs with available all-grade proteinuria data were included for the analysis $[7,8,12,22,23,26,30,32,37,39-41,44,45$, $49,55,58,60,63-66,72-74,76,79]$. For the patients administered with bevacizumab, our results demonstrated that the summary event rate was $18 \%$ (95\% CI: $11.7 \%$ $26.6 \%$ ) calculated in a random-effect model. For trials excluding rental cancer, the incidence was $14.3 \%$ (95\% CI 9.4\%-21.2\%, Supplementary Table 3), but no significant difference was discovered with and without rental cancer $(P=0.502)$. Compared with controls, the RR was 3.369 (95\% CI: 2.492-4.556), indicating an obviously increased risk for all-grade proteinuria with bevacizumab. In the subgroup analysis by the dosage, the RR for low-dose bevacizumab was 2.124 (95\% CI: 1.557-2.897), and the RR for high-dose was 4.225 (95\% CI: 2.923-6.106) as shown in Figure 3B. But, no significant difference $(P=0.311)$ was existed between the low and high dosage of bevacizumab. Subgroup analysis based on caner types, the incidence of all-grade proteinuria ranged from 4.4\% (95\% CI: 3.2\%-6.2\%) for ovarian cancer to $47.1 \%$ (95\% CI: $17.3 \%-79.1 \%)$ for rental cancer (Supplementary Table 3). But, no significant difference was discovered between various caner types $(P=0.065)$. In addition, we also conducted subgroup analysis base on treatment line and phase of trials. No significant difference was observed between patients in phase II and phase III trials (RR: 2.579 VS. 3.983, $P=$ $0.397)$, which was similar to the result between per-treated patients and native-treated patients (RR: 3.574 VS. 2.973, $P=0.517$, Supplementary Table 3 ). Stratified analysis by concomitant drugs, although significantly increased risks were observed in all concomitant drugs, no significant different were observed $(P=0.536)$, with the highest RR in conjunction with cyclophosphamide 11.515 (95\% CI: 2.106-62.9) and the lowest RR in combination with taxane 2.381 (95\% CI: 1.690-3.354, Supplementary Table $3)$. Besides, we also did subgroup analysis according to the length of bevacizumab treatment duration. Patients with long treatment had the RR of 2.893 (95\% CI: 1.304 $6.416)$, while others in short treatment had the RR of 10.14 (95\% CI: 6.926-14.86). But, no obvious difference was obtained between the short and long treatment $(P=$ 0.877 , Supplementary Table 3 ). Finally, subgroup analysis base on the age of patients was also conducted, but no significant difference was observed between patients $<60$ and $\geq 60$ years (RR: 2.382 VS. 3.406, $P=0.424$ ). Because the limited number of patients in each trial and the limited number of enrolled RCTs, more cautious should be paid when interpreting those results.

\section{Publication bias}

We carried out Begg's funnel plot and Egger's test to assess the publication bias of the included studies. As shown in Figure 5, the shape of the funnel plots seemed asymmetrical in all and high-grade proteinuria analysis, indicating the existing of publication bias. Then, we performed the Egger's test to provide statistical evidence for funnel plot asymmetry. As expected, the results showed obvious evidence of publication bias for allgrade $(t=0.293, \mathrm{Z}=2.23, P=0.026)$ and high-grade proteinuria $(t=-0.339, \mathrm{Z}=3.48, P=0.0005)$, but not for all-grade $(t=0.09, \mathrm{Z}=0.84, P=0.0 .40)$ and highgrade hypertension $(t=0.02, \mathrm{Z}=0.27, P=0.79$, Figure 5). A trimand-fill method developed by Duval and Tweedie 


\section{A RR of high-grade proeinuria with bevacizumab $2.5 \mathrm{mg} / \mathrm{kg} / \mathrm{week}$}

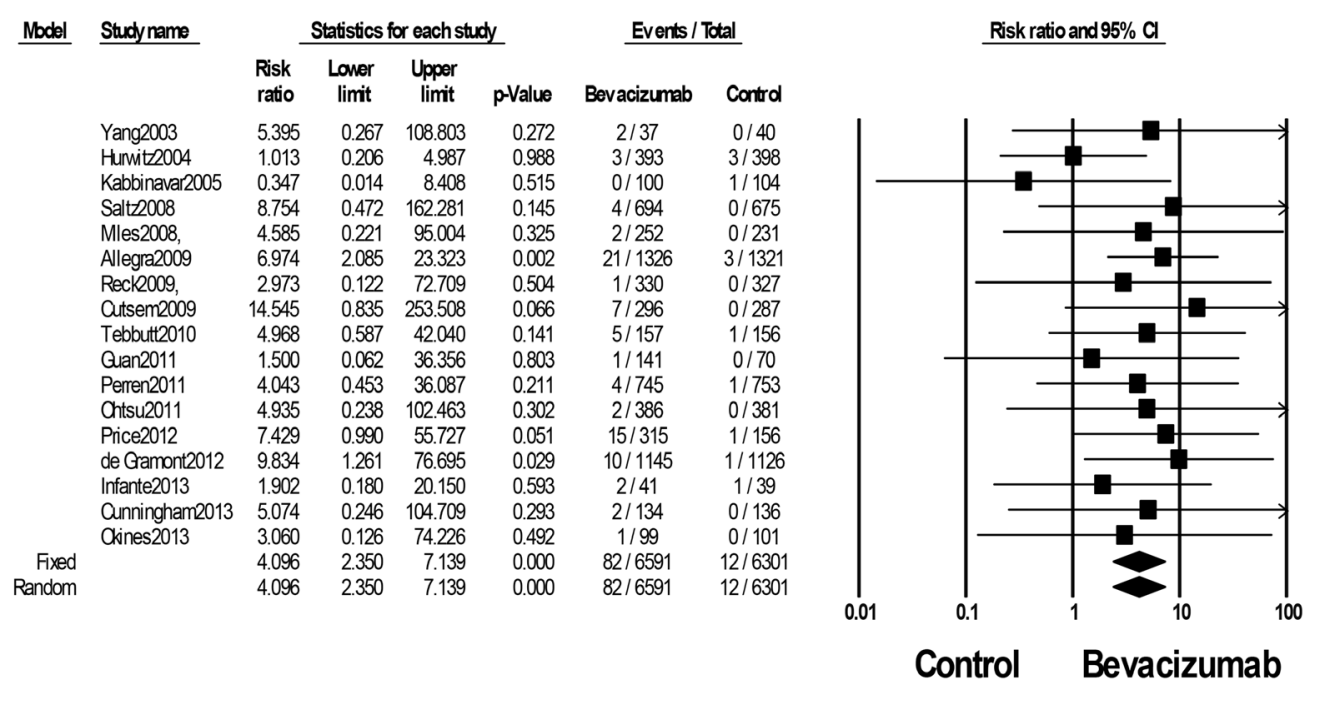

meta analysis

\section{B RR of high-grade proteinuria with bevacizumab $5 \mathrm{mg} / \mathrm{kg} / \mathrm{week}$}

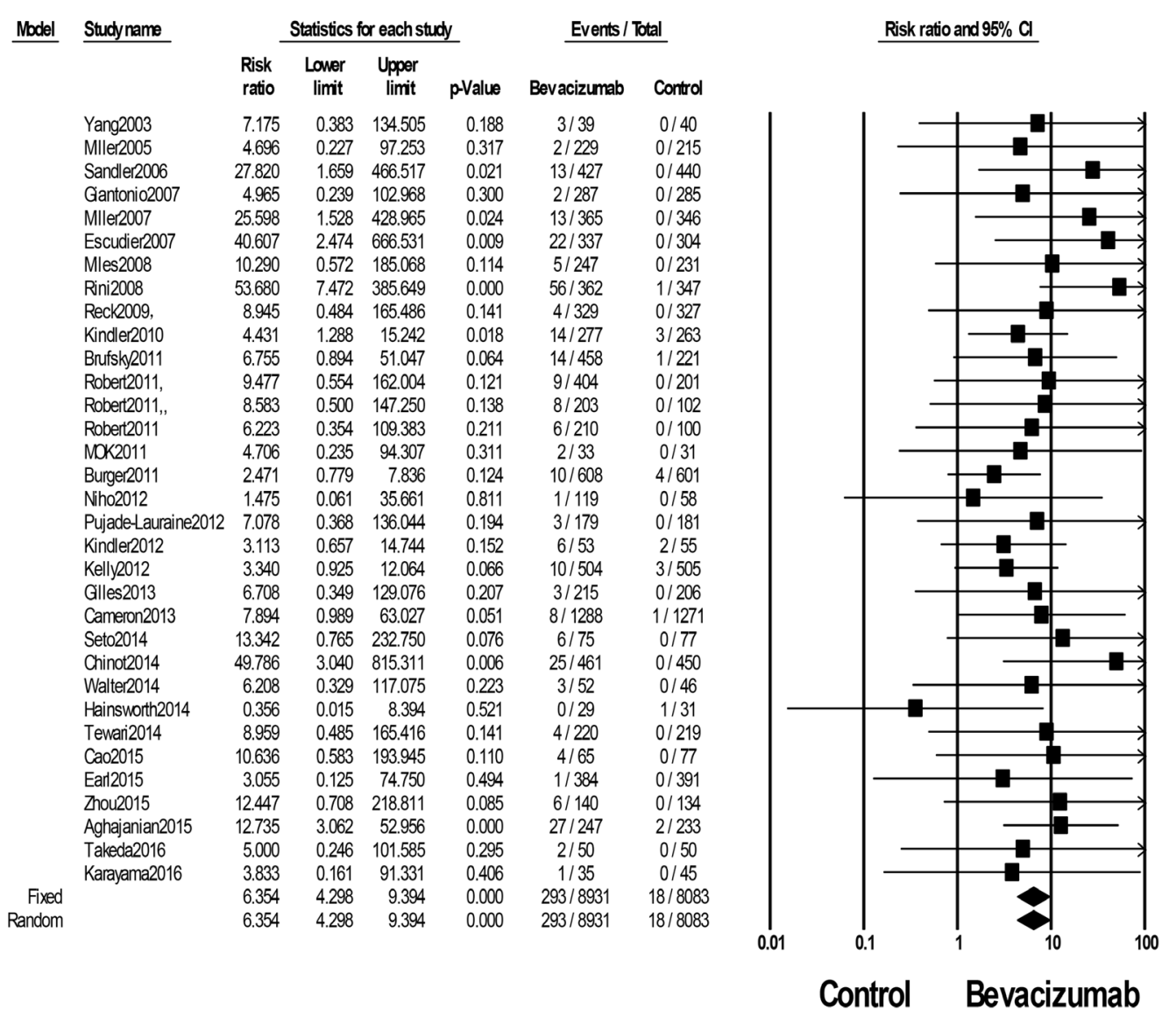

meta analysis

Figure 4: RRs of high-grade proteinuria for cancer patients who received (A) low-dose and (B) high-dose bevacizumab compared with controls. 
was performed to adjust for this bias. No different conclusions were drawn with or without the trim-and-fill method, which indicating that our results were statistically robust [82].

\section{DISCUSSION}

Bevacizumab has been clinically validated as a targeted agent against various cancers and also may lead to a great deal of adverse effects [19]. Because proteinuria and hypertension are vital risk factors for renal and cardiovascular events, it is particularly essential to recognize and take adequate and aggressive management to monitor and manage those risks timely and appropriately. So, our present meta-analysis systematically investigated the comprehensive association

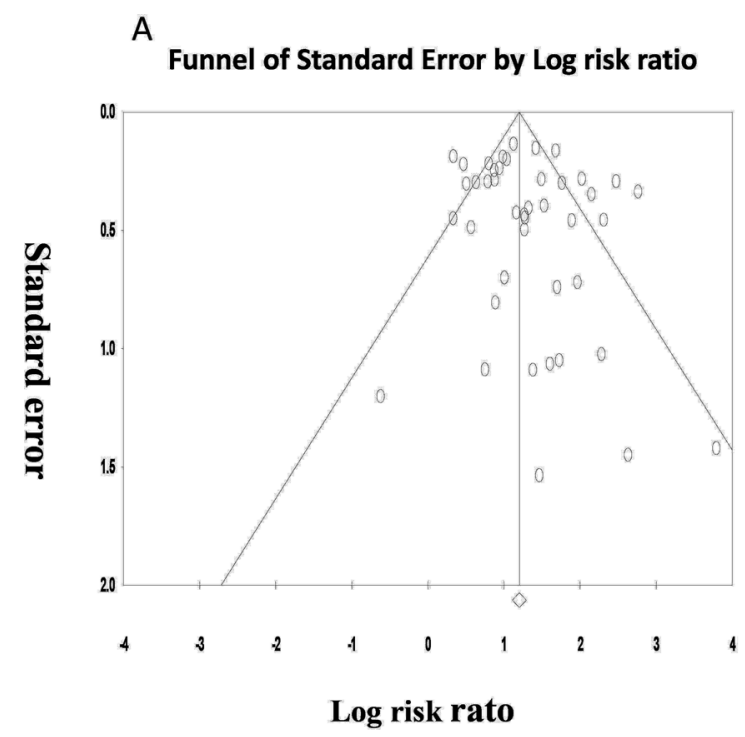

\section{C}

Funnel of Standard Error by Log risk ratio

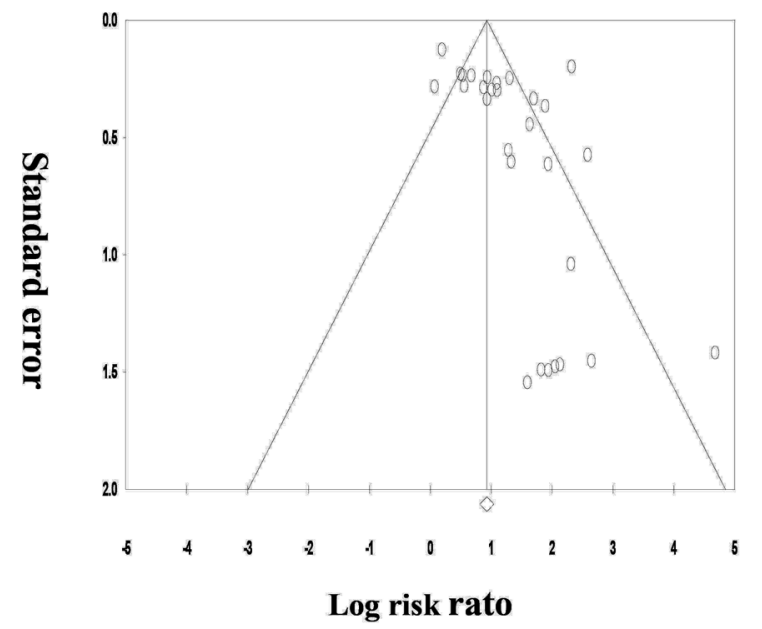

between the increased risks and incidence of proteinuria and hypertension associated with bevacizumab among different cancer patients.

Our study demonstrated that bevacizumab was associated with a significantly increased risks for allgrade (RR: 3.369, 95\% CI: 2.492-4.556) and highgrade proteinuria (RR: 5.494 , 95\% CI: 3.991-7.564) in comparison with controls. In clinical, angiotensin receptor blockers and angiotensin-converting enzyme inhibitors were normally used to manage bevacizumab related proteinuria. In addition, bevacizumab was recommended to temporarily suspended for patients with urine protein excretion more than $2 \mathrm{~g} / 24 \mathrm{~h}$, and resumed when it was less than $2 \mathrm{~g} / 24 \mathrm{~h}$ [20]. Consistent with the results of proteinuria, we also showed that RR for all-grade hypertension was 3.595 (95\% CI: 2.952-4.378) and for high-grade hypertension was 5.173 (95\% CI: 4.188-6.390).

B

Funnel of Standard Error by Log risk ratio

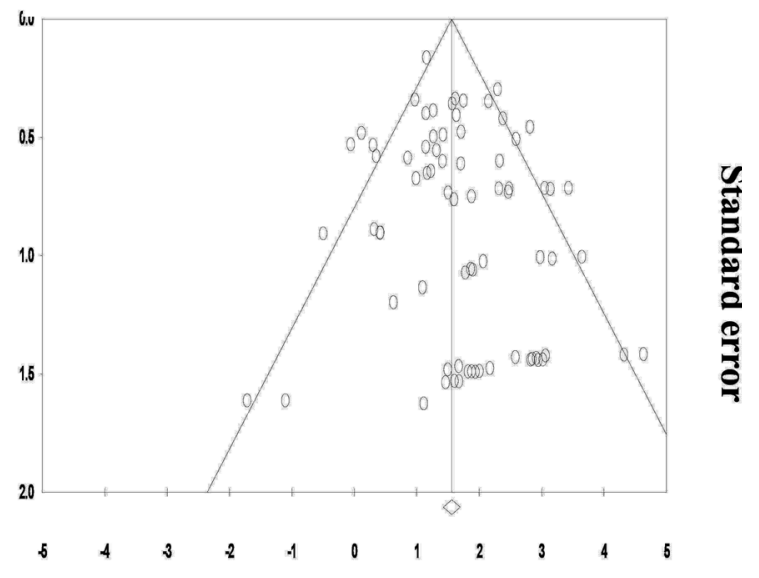

Log risk rato

D

Funnel of Standard Error by Log risk ratio

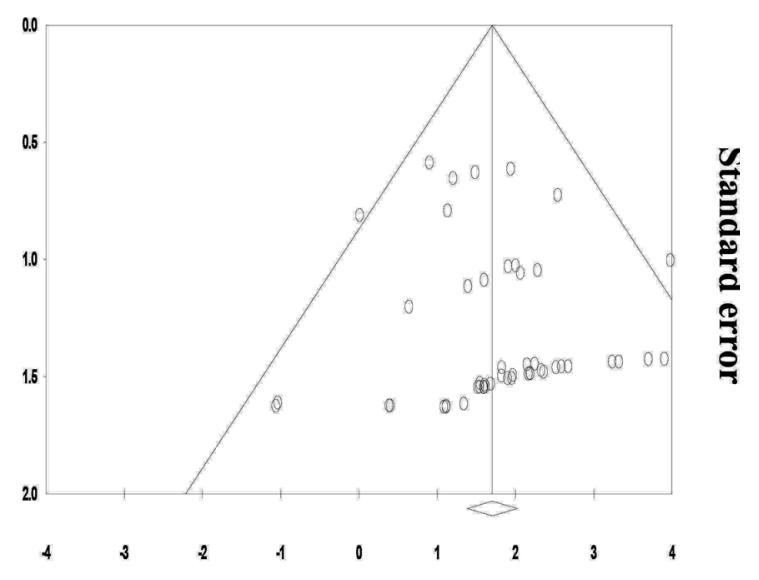

Log risk rato

Figure 5: Funnel-plot standard error based on the risk ratio for relative risk of (A) all-grade hypertension and (B) high-grade hypertension (C) all-grade proteinuria and (D) high-grade proteinuria. 
Now, hypertension resulted from bevacizumab was managed by oral antihypertensive medications [83]. In clinical practice, $\beta$-adrenoceptor antagonists, angiotensin converting enzyme inhibitors, angiotensin-receptor antagonists, and calcium antagonists may be used either in alone or in combination [84]. Besides, it was also recommended to temporary/permanent suspension or even hospitalization when severe hypertension could not be controlled by medications [19]. Above all, in order to properly manage hypertension and proteinuria, we should fully understand the pathogenesis of bevacizumabassociated renal toxicities and then select suitable therapeutic schemes in clinical practice.

Hypertension induced by bevacizumab may involve multiple reasons. Firstly, appropriate VEGF produced by podocytes could activate VEGF receptor on glomerular capillary endothelial cells to maintain the normal structure and function [85]. Whereas, bevacizumab, the VEGF inhibitor, would increase cell apoptosis and decrease endothelial renewal capacity [86]. Secondly, bevacizumab may suppress the production of vasodilators such as nitrous oxide and prostacyclin, which may in turn lead to vasoconstriction and decreased sodium ion renal excretion $[87,88]$. Beside, bevacizumab may decrease the number of arterioles and capillaries, resulting in an increase in peripheral vascular resistance [89]. All of the above may be the explanations for bevacizumab related hypertension.

The pathogenesis for proteinuria induced by bevacizumab may also attribute to several pathways. First of all, bevacizumab could reduce proliferation of podocytes and endothelial cells due to the decreased renewal capacity [90]. Those proliferative changes would reduce the selection of protein filtration, which may lead to various levels of proteinuria and other clinical symptoms [91, 92]. In addition, hypertension induced by bevacizumab could increase intraglomerular pressure, thereby resulting in much more protein filtration [55]. But it was still unclear whether hypertension lead to proteinuria or both were resulted from bevacizumab independently.

Further stratified analyses based on various clinical characters were conducted to explore the confounding bias for the increased risks. Firstly, our meta-analysis suggested that patients accepted high-dose of bevacizumab at $5 \mathrm{mg} / \mathrm{kg} /$ week had nearly double RR than those received low-dose at $2.5 \mathrm{mg} / \mathrm{kg} / \mathrm{week}$, which indicated that the increased risks of hypertension and proteinuria were dosedependent. So, we could reduce the dosage to decrease the risks when bevacizumab must be used. Secondly, our study also showed that the risks for high-grade proteinuria and hypertension varied with tumor types, with the particularly highest risk for rental cancer. The explanation for this phenomenon may be that nephrectomy conducted among rental cancer patients could decrease glomerular filtration, which may lead to an underlying renal insufficiency. Consequently, a higher concentration of bevacizumab would aggravate the relative risks [93]. It was also possible that the hypertrophy of the postnephrectomy glomerular for rental cancer patients may become more dependence on VEGF to maintain structural integrity than a normal kidney, resulting in more susceptibility to bevacizumab [21]. Thirdly, stratified by concomitant drags, we found that the risks of proteinuric and hypertension may obvious augment when used in conjunction with interferonalfa, anthracycline or capecitabine. So, oncologists should be cautious to choose the relative lower toxicity concomitant drags for patients accepted bevacizumab. Whereas, no significant difference were discovered when stratified based on phase of trials, age of patients, treatment line and duration. So these factors should not be as the major considerations in the use of bevacizumab. Above all, clinicians should pay more attention when adding bevacizumab for the treatment of various cancers.

In conclusion, our study showed that bevacizumab significantly increased the risks of proteinuria and hypertension for cancer patients. Those risks may be dependent on dosage and vary with tumor types and concomitant drugs. So, early monitor and effective management of the risks may play vital role in more extensive and safer use of bevacizumab in clinical. Besides, future more studies were strongly encouraged to uncover the mechanisms of bevacizumab induced hypertension and proteinuria, and then guided therapy for these adverse effects.

\section{MATERIALS AND METHODS}

\section{Identification and eligibility of relevant studies}

Pubmed, Embase, Medline, and the Chinese Biomedical (CBM) databases were extensive searched using several search terms: "anti-VEGF antibody", "bevacizumab", "avastin", "cancer", "tumor", "chemotherapy", "adverse effects", "proteinuria", "hypertension", "randomized controlled trials" and "RCTs" (last search updated on October, 2016). Additional literatures were identified by a handed search of the references of the original studies and reviews. In order to ensure that no clinical trials were overlooked, we also performed an independent search using the citation database Web of Science developed by the institute for scientific information. In the event that studies featured duplicate data, we incorporated all of the studies with various chemotherapy drugs and different follow-up time. If the relevant data were not freely available, we tried our best to contact investigators. Finally, we obtained further pertinent information by reviewing the updated manufacturer's package insert of bevacizumab.

\section{Study selection}

Two investigators independently executed the literature search and examined RCTs to accurately assess the contribution of bevacizumab to the development of hypertension and proteinuria. Phase I trials and single-arm 
phase II trials were excluded from our present analysis. At last, the studies meeting the following criteria were selected for our meta-analysis; 1) prospective phase II or III RCTs, 2) random assignment of patients to either a case group combined treatment of bevacizumab and concurrent chemotherapy or a control group with chemotherapy alone, and 3) available data including the number of patients with hypertension or proteinuria for case and control groups (both high-grade or all-grade). Finally, 72 studies were included in our analysis and quality was assessed using previously described criteria including adequate blinding of randomization, completeness of follow-up, and objectivity of outcome measurement [94].

\section{Data extraction}

The following data from these selected trials were independently extracted by two reviewers: the first author's last name, year of publication, cancer types, trial phase, trial line, age, the follow-up time, treatment duration, the number of enrolled patients, the number of intervention and control patients, concurrent chemotherapy, and bevacizumab dose. Any discrepancies between reviewers were resolved by consensus. Both hypertension and proteinuria were recorded according to version $1,2,3$ or 4 of the National Cancer Institute's Common Terminology Criteria for Adverse Events (CTCAE, http://ctep.cancer. gov/reporting/ctc_archive.html), which have been widely used in cancer clinical trials [95]. And both versions were similar regarding hypertension and proteinuria.

\section{Statistical analysis}

We carried out all statistical analyses by the version 2 comprehensive meta-analysis program (Biostat, Englewood, NJ) [96]. Tthe overall incidence, risk ratios (RRs), and 95\% confidence intervals (95\% CIs) of patients with hypertension and proteinuria for each trial were calculated. And due to a possible correlation between rental cancer and proteinuria, we also carried out a separate analysis for proteinuria without rental cancer. Choosing a fixed or random-effect model was based on the heterogeneity estimated by calculating both Cochran $Q$ statistic and $\mathrm{I}^{2}$ [97]. If the $P$ value of Cochran Q statistic $<0.05$, indicating a lack of homogeneity across study, so the result was reported by a random-effect model. Otherwise, fixed-effect model was adopted. Furthermore, Begg's funnel plots and Egger's linear regression test were applied to assess the publication bias. A two-tailed $P$ value $<0.05$ was judged as statistically significant.

\section{ACKNOWLEDGMENTS AND FUNDING}

The authors acknowledge the support from National Basic Research Program of China 973 Program No.2014CBA02005.

\section{CONFLICTS OF INTEREST}

The authors have no conflicts of interest to declare.

\section{REFERENCES}

1. Cavallaro U, Christofori G. Molecular mechanisms of tumor angiogenesis and tumor progression. J Neurooncol. 2000; 50:63-70.

2. Folkman J. Role of angiogenesis in tumor growth and metastasis. Semin Oncol. 2002; 29:15-8.

3. Hicklin DJ, Ellis LM. Role of the vascular endothelial growth factor pathway in tumor growth and angiogenesis. J Clin Oncol. 2005; 23:1011-27.

4. Gerber HP, Ferrara N. Pharmacology and pharmacodynamics of bevacizumab as monotherapy or in combination with cytotoxic therapy in preclinical studies. Cancer Res. 2005; 65:671-80.

5. Hegewisch-Becker S, Graeven U, Lerchenmuller CA, Killing B, Depenbusch R, Steffens CC, Al-Batran SE, Lange T, Dietrich G, Stoehlmacher J, Tannapfel A, Reinacher-Schick A, Quidde J, et al. Maintenance strategies after first-line oxaliplatin plus fluoropyrimidine plus bevacizumab for patients with metastatic colorectal cancer (AIO 0207):a randomised, non-inferiority, open-label, phase 3 trial. Lancet Oncol. 2015; 16:1355-69.

6. Nahleh ZA, Barlow WE, Hayes DF, Schott AF, Gralow JR, Sikov WM, Perez EA, Chennuru S, Mirshahidi HR, Corso SW, Lew DL, Pusztai L, Livingston RB, et al. SWOG S0800 (NCI CDR0000636131): addition of bevacizumab to neoadjuvant nab-paclitaxel with dose-dense doxorubicin and cyclophosphamide improves pathologic complete response (pCR) rates in inflammatory or locally advanced breast cancer. Breast Cancer Res Treat. 2016; 158:485-95.

7. Takeda M, Yamanaka T, Seto T, Hayashi H, Azuma K, Okada M, Sugawara S, Daga H, Hirashima T, Yonesaka K, Urata Y, Murakami H, Saito H, et al. Bevacizumab beyond disease progression after first-line treatment with bevacizumab plus chemotherapy in advanced nonsquamous non-small cell lung cancer (West Japan Oncology Group 5910L): An open-label, randomized, phase 2 trial. Cancer. 2016; 122:1050-9.

8. Rini BI, Halabi S, Rosenberg JE, Stadler WM, Vaena DA, Archer L, Atkins JN, Picus J, Czaykowski P, Dutcher J, Small EJ. Phase III trial of bevacizumab plus interferon alfa versus interferon alfa monotherapy in patients with metastatic renal cell carcinoma: final results of CALGB 90206. J Clin Oncol. 2010; 28:2137-43.

9. Aghajanian C, Goff B, Nycum LR, Wang YV, Husain A, Blank SV. Final overall survival and safety analysis of OCEANS, a phase 3 trial of chemotherapy with or without bevacizumab in patients with platinum-sensitive recurrent ovarian cancer. Gynecol Oncol. 2015; 139:10-6.

10. Kindler HL, Niedzwiecki D, Hollis D, Sutherland S, Schrag D, Hurwitz H, Innocenti F, Mulcahy MF, O’Reilly E, 
Wozniak TF, Picus J, Bhargava P, Mayer RJ, et al. Gemcitabine plus bevacizumab compared with gemcitabine plus placebo in patients with advanced pancreatic cancer: phase III trial of the Cancer and Leukemia Group B (CALGB 80303). J Clin Oncol. 2010; 28:3617-22.

11. Okines AF, Langley RE, Thompson LC, Stenning SP, Stevenson L, Falk S, Seymour M, Coxon F, Middleton GW, Smith D, Evans L, Slater S, Waters J, et al. Bevacizumab with peri-operative epirubicin, cisplatin and capecitabine (ECX) in localised gastro-oesophageal adenocarcinoma: a safety report. Ann Oncol. 2013; 24:702-9.

12. Chinot OL, Wick W, Mason W, Henriksson R, Saran F, Nishikawa R, Carpentier AF, Hoang-Xuan K, Kavan P, Cernea D, Brandes AA, Hilton M, Abrey L, et al. Bevacizumab plus radiotherapy-temozolomide for newly diagnosed glioblastoma. N Engl J Med. 2014; 370:709-22.

13. Hainsworth JD, Greco FA, Raefsky EL, Thompson DS, Lunin S, Reeves J Jr, White L, Quinn R, DeBusk LM, Flinn IW. Rituximab with or without bevacizumab for the treatment of patients with relapsed follicular lymphoma. Clin Lymphoma Myeloma Leuk. 2014; 14:277-83.

14. White D, Kassim A, Bhaskar B, Yi J, Wamstad K, Paton VE. Results from AMBER, a randomized phase 2 study of bevacizumab and bortezomib versus bortezomib in relapsed or refractory multiple myeloma. Cancer. 2013; 119:339-47.

15. Kindler HL, Karrison TG, Gandara DR, Lu C, Krug LM, Stevenson JP, Janne PA, Quinn DI, Koczywas MN, Brahmer JR, Albain KS, Taber DA, Armato SG 3rd, et al. Multicenter, double-blind, placebo-controlled, randomized phase II trial of gemcitabine/cisplatin plus bevacizumab or placebo in patients with malignant mesothelioma. J Clin Oncol. 2012; 30:2509-15.

16. Kelly WK, Halabi S, Carducci M, George D, Mahoney JF, Stadler WM, Morris M, Kantoff P, Monk JP, Kaplan E, Vogelzang NJ, Small EJ. Randomized, double-blind, placebo-controlled phase III trial comparing docetaxel and prednisone with or without bevacizumab in men with metastatic castration-resistant prostate cancer: CALGB 90401. J Clin Oncol. 2012; 30:1534-40.

17. Tewari KS, Sill MW, Long HJ 3rd, Penson RT, Huang H, Ramondetta LM, Landrum LM, Oaknin A, Reid TJ, Leitao MM, Michael HE, Monk BJ. Improved survival with bevacizumab in advanced cervical cancer. N Engl J Med. 2014; 370:734-43.

18. Hensley ML, Miller A, O’Malley DM, Mannel RS, Behbakht K, Bakkum-Gamez JN, Michael H. Randomized phase III trial of gemcitabine plus docetaxel plus bevacizumab or placebo as first-line treatment for metastatic uterine leiomyosarcoma: an NRG Oncology/Gynecologic Oncology Group study. J Clin Oncol. 2015; 33:1180-5.

19. Shimoyama T. [Bevacizumab (Avastin)]. [Article in Japanese]. Gan To Kagaku Ryoho. 2009; 36:523-30.

20. Zhu X, Wu S, Dahut WL, Parikh CR. Risks of proteinuria and hypertension with bevacizumab, an antibody against vascular endothelial growth factor: systematic review and meta-analysis. Am J Kidney Dis. 2007; 49:186-93.

21. Wu S, Kim C, Baer L, Zhu X. Bevacizumab increases risk for severe proteinuria in cancer patients. J Am Soc Nephrol. 2010; 21:1381-9.

22. Earl HM, Hiller L, Dunn JA, Blenkinsop C, Grybowicz L, Vallier AL, Abraham J, Thomas J, Provenzano E, HughesDavies L, Gounaris I, McAdam K, Chan S, et al. Efficacy of neoadjuvant bevacizumab added to docetaxel followed by fluorouracil, epirubicin, and cyclophosphamide, for women with HER2-negative early breast cancer (ARTemis): an open-label, randomised, phase 3 trial. Lancet Oncol. 2015; 16:656-66.

23. Seto T, Kato T, Nishio M, Goto K, Atagi S, Hosomi Y, Yamamoto N, Hida T, Maemondo M, Nakagawa K, Nagase S, Okamoto I, Yamanaka T, et al. Erlotinib alone or with bevacizumab as first-line therapy in patients with advanced non-squamous non-small-cell lung cancer harbouring EGFR mutations (JO25567): an open-label, randomised, multicentre, phase 2 study. Lancet Oncol. 2014; 15:1236-44.

24. Allegra CJ, Yothers G, O'Connell MJ, Sharif S, Petrelli NJ, Lopa SH, Wolmark N. Bevacizumab in stage II-III colon cancer:5-year update of the National Surgical Adjuvant Breast and Bowel Project C-08 trial. J Clin Oncol. 2013; 31:359-64.

25. Ranpura V, Pulipati B, Chu D, Zhu X, Wu S. Increased risk of high-grade hypertension with bevacizumab in cancer patients: a meta-analysis. Am J Hypertens. 2010; 23:460-8.

26. Allegra CJ, Yothers G, O'Connell MJ, Sharif S, Colangelo LH, Lopa SH, Petrelli NJ, Goldberg RM, Atkins JN, Seay TE, Fehrenbacher L, O'Reilly S, Chu L, et al. Initial safety report of NSABP C-08: A randomized phase III study of modified FOLFOX6 with or without bevacizumab for the adjuvant treatment of patients with stage II or III colon cancer. J Clin Oncol. 2009; 27:3385-90.

27. Bennouna J, Sastre J, Arnold D, Osterlund P, Greil R, Van Cutsem E, von Moos R, Vieitez JM, Bouche O, Borg C, Steffens CC, Alonso-Orduna V, Schlichting C, et al. Continuation of bevacizumab after first progression in metastatic colorectal cancer (ML18147): a randomised phase 3 trial. Lancet Oncol. 2013; 14:29-37.

28. Cao R, Zhang S, Ma D, Hu L. A multi-center randomized phase II clinical study of bevacizumab plus irinotecan, 5-fluorouracil, and leucovorin (FOLFIRI) compared with FOLFIRI alone as second-line treatment for Chinese patients with metastatic colorectal cancer. Med Oncol. 2015; 32:325.

29. Bevacizumab in combination with irinotecan plus fluorouracil plus leucovorin chemotherapy prolongs survival but increases adverse events in people with metastatic colorectal cancer. Cancer Treat Rev. 2004; 30:715-7.

30. Cunningham D, Lang I, Marcuello E, Lorusso V, Ocvirk J, Shin DB, Jonker D, Osborne S, Andre N, Waterkamp D, Saunders MP; AVEX study investigators. Bevacizumab plus capecitabine versus capecitabine alone in elderly patients with previously untreated metastatic colorectal cancer 
(AVEX): an open-label, randomised phase 3 trial. Lancet Oncol. 2013; 14:1077-85.

31. Dotan E, Meropol NJ, Burtness B, Denlinger CS, Lee J, Mintzer D, Zhu F, Ruth K, Tuttle H, Sylvester J, Cohen SJ. A phase II study of capecitabine, oxaliplatin, and cetuximab with or without bevacizumab as frontline therapy for metastatic colorectal cancer. A Fox Chase extramural research study. J Gastrointest Cancer. 2012; 43:562-9.

32. Giantonio BJ, Catalano PJ, Meropol NJ, O'Dwyer PJ, Mitchell EP, Alberts SR, Schwartz MA, Benson AB 3rd, Eastern Cooperative Oncology Group Study E. Bevacizumab in combination with oxaliplatin, fluorouracil, and leucovorin (FOLFOX4) for previously treated metastatic colorectal cancer: results from the Eastern Cooperative Oncology Group Study E3200. J Clin Oncol. 2007; 25:1539-44.

33. Guan ZZ, Xu JM, Luo RC, Feng FY, Wang LW, Shen L, Yu SY, Ba Y, Liang J, Wang D, Qin SK, Wang JJ, He J, et al. Efficacy and safety of bevacizumab plus chemotherapy in Chinese patients with metastatic colorectal cancer: a randomized phase III ARTIST trial. Chin J Cancer. 2011; 30:682-9.

34. Hochster HS, Hart LL, Ramanathan RK, Childs BH, Hainsworth JD, Cohn AL, Wong L, Fehrenbacher L, Abubakr Y, Saif MW, Schwartzberg L, Hedrick E. Safety and efficacy of oxaliplatin and fluoropyrimidine regimens with or without bevacizumab as first-line treatment of metastatic colorectal cancer: results of the TREE Study. J Clin Oncol. 2008; 26:3523-9.

35. Berretta M, Lleshi A, Zanet E, Bearz A, Simonelli C, Fisichella R, Nasti G, Berretta S, Tirelli U. Bevacizumab plus irinotecan-, fluorouracil-, and leucovorin-based chemotherapy with concomitant HAART in an HIV-positive patient with metastatic colorectal cancer. Onkologie. 2008; 31:394-7.

36. Hurwitz HI, Yi J, Ince W, Novotny WF, Rosen O. The clinical benefit of bevacizumab in metastatic colorectal cancer is independent of K-ras mutation status: analysis of a phase III study of bevacizumab with chemotherapy in previously untreated metastatic colorectal cancer. Oncologist. 2009; 14:22-8.

37. Infante JR, Reid TR, Cohn AL, Edenfield WJ, Cescon TP, Hamm JT, Malik IA, Rado TA, McGee PJ, Richards DA, Tarazi J, Rosbrook B, Kim S, et al. Axitinib and/or bevacizumab with modified FOLFOX-6 as first-line therapy for metastatic colorectal cancer: a randomized phase 2 study. Cancer. 2013; 119:2555-63.

38. Kabbinavar F, Hurwitz HI, Fehrenbacher L, Meropol NJ, Novotny WF, Lieberman G, Griffing S, Bergsland E. Phase II, randomized trial comparing bevacizumab plus fluorouracil (FU)/leucovorin (LV) with FU/LV alone in patients with metastatic colorectal cancer. J Clin Oncol. 2003; 21:60-5.

39. Kabbinavar FF, Schulz J, McCleod M, Patel T, Hamm JT, Hecht JR, Mass R, Perrou B, Nelson B, Novotny WF. Addition of bevacizumab to bolus fluorouracil and leucovorin in first-line metastatic colorectal cancer: results of a randomized phase II trial. J Clin Oncol. 2005; 23:3697-705.

40. Passardi A, Nanni O, Tassinari D, Turci D, Cavanna L, Fontana A, Ruscelli S, Mucciarini C, Lorusso V, Ragazzini A, Frassineti GL, Amadori D. Effectiveness of bevacizumab added to standard chemotherapy in metastatic colorectal cancer: final results for first-line treatment from the ITACa randomized clinical trial. Ann Oncol. 2015; 26:1201-7.

41. Tebbutt NC, Wilson K, Gebski VJ, Cummins MM, Zannino D, van Hazel GA, Robinson B, Broad A, Ganju V, Ackland SP, Forgeson G, Cunningham D, Saunders MP, et al. Capecitabine, bevacizumab, and mitomycin in firstline treatment of metastatic colorectal cancer: results of the Australasian Gastrointestinal Trials Group Randomized Phase III MAX Study. J Clin Oncol. 2010; 28:3191-8.

42. Price TJ, Zannino D, Wilson K, Simes RJ, Cassidy J, Van Hazel GA, Robinson BA, Broad A, Ganju V, Ackland SP, Tebbutt NC. Bevacizumab is equally effective and no more toxic in elderly patients with advanced colorectal cancer: a subgroup analysis from the AGITG MAX trial: an international randomised controlled trial of Capecitabine, Bevacizumab and Mitomycin C. Ann Oncol. 2012; 23:1531-6.

43. Saltz LB, Clarke S, Diaz-Rubio E, Scheithauer W, Figer A, Wong R, Koski S, Lichinitser M, Yang TS, Rivera F, Couture F, Sirzen F, Cassidy J. Bevacizumab in combination with oxaliplatin-based chemotherapy as first-line therapy in metastatic colorectal cancer: a randomized phase III study. J Clin Oncol. 2008; 26:2013-9.

44. Stathopoulos GP, Batziou C, Trafalis D, Koutantos J, Batzios S, Stathopoulos J, Legakis J, Armakolas A. Treatment of colorectal cancer with and without bevacizumab: a phase III study. Oncology. 2010; 78:376-81.

45. Hurwitz H, Fehrenbacher L, Novotny W, Cartwright T, Hainsworth J, Heim W, Berlin J, Baron A, Griffing S, Holmgren E, Ferrara N, Fyfe G, Rogers B, et al. Bevacizumab plus irinotecan, fluorouracil, and leucovorin for metastatic colorectal cancer. N Engl J Med. 2004; 350:2335-42.

46. Bear HD, Tang G, Rastogi P, Geyer CE Jr, Robidoux A, Atkins JN, Baez-Diaz L, Brufsky AM, Mehta RS, Fehrenbacher L, Young JA, Senecal FM, Gaur R, et al. Bevacizumab added to neoadjuvant chemotherapy for breast cancer. N Engl J Med. 2012; 366:310-20.

47. Bear HD, Tang G, Rastogi P, Geyer CE Jr, Liu Q, Robidoux A, Baez-Diaz L, Brufsky AM, Mehta RS, Fehrenbacher L, Young JA, Senecal FM, Gaur R, et al. Neoadjuvant plus adjuvant bevacizumab in early breast cancer (NSABP B-40 [NRG Oncology]): secondary outcomes of a phase 3, randomised controlled trial. Lancet Oncol. 2015; 16:1037-48.

48. Brufsky AM, Hurvitz S, Perez E, Swamy R, Valero V, O'Neill V, Rugo HS. RIBBON-2: a randomized, doubleblind, placebo-controlled, phase III trial evaluating the efficacy and safety of bevacizumab in combination 
with chemotherapy for second-line treatment of human epidermal growth factor receptor 2-negative metastatic breast cancer. J Clin Oncol. 2011; 29:4286-93.

49. Cameron D, Brown J, Dent R, Jackisch C, Mackey J, Pivot X, Steger GG, Suter TM, Toi M, Parmar M, Laeufle R, Im YH, Romieu G, et al. Adjuvant bevacizumab-containing therapy in triple-negative breast cancer (BEATRICE): primary results of a randomised, phase 3 trial. Lancet Oncol. 2013; 14:933-42.

50. Coudert B, Pierga JY, Mouret-Reynier MA, Kerrou K, Ferrero JM, Petit T, Kerbrat P, Dupre PF, Bachelot T, Gabelle P, Giard S, Coeffic D, Bougnoux P, et al. Use of [(18)F]-FDG PET to predict response to neoadjuvant trastuzumab and docetaxel in patients with HER2-positive breast cancer, and addition of bevacizumab to neoadjuvant trastuzumab and docetaxel in [(18)F]-FDG PET-predicted non-responders (AVATAXHER): an open-label, randomised phase 2 trial. Lancet Oncol. 2014; 15:1493-502.

51. Gianni L, Romieu GH, Lichinitser M, Serrano SV, Mansutti M, Pivot X, Mariani P, Andre F, Chan A, Lipatov O, Chan S, Wardley A, Greil R, et al. AVEREL: a randomized phase III Trial evaluating bevacizumab in combination with docetaxel and trastuzumab as first-line therapy for HER2-positive locally recurrent/metastatic breast cancer. J Clin Oncol. 2013; 31:1719-25.

52. Martin M, Roche H, Pinter T, Crown J, Kennedy MJ, Provencher L, Priou F, Eiermann W, Adrover E, Lang I, Ramos M, Latreille J, Jagiello-Gruszfeld A, et al. Motesanib, or open-label bevacizumab, in combination with paclitaxel, as first-line treatment for HER2-negative locally recurrent or metastatic breast cancer: a phase 2, randomised, double-blind, placebo-controlled study. Lancet Oncol. 2011; 12:369-76.

53. Miles DW, Chan A, Dirix LY, Cortes J, Pivot X, Tomczak P, Delozier T, Sohn JH, Provencher L, Puglisi F, Harbeck N, Steger GG, Schneeweiss A, et al. Phase III study of bevacizumab plus docetaxel compared with placebo plus docetaxel for the first-line treatment of human epidermal growth factor receptor 2-negative metastatic breast cancer. J Clin Oncol. 2010; 28:3239-47.

54. Miller K, Wang M, Gralow J, Dickler M, Cobleigh M, Perez EA, Shenkier T, Cella D, Davidson NE. Paclitaxel plus bevacizumab versus paclitaxel alone for metastatic breast cancer. N Engl J Med. 2007; 357:2666-76.

55. Miller KD, Chap LI, Holmes FA, Cobleigh MA, Marcom PK, Fehrenbacher L, Dickler M, Overmoyer BA, Reimann JD, Sing AP, Langmuir V, Rugo HS. Randomized phase III trial of capecitabine compared with bevacizumab plus capecitabine in patients with previously treated metastatic breast cancer. J Clin Oncol. 2005; 23:792-9.

56. Robert NJ, Dieras V, Glaspy J, Brufsky AM, Bondarenko I, Lipatov ON, Perez EA, Yardley DA, Chan SY, Zhou X, Phan SC, O'Shaughnessy J. RIBBON-1: randomized, doubleblind, placebo-controlled, phase III trial of chemotherapy with or without bevacizumab for first-line treatment of human epidermal growth factor receptor 2-negative, locally recurrent or metastatic breast cancer. J Clin Oncol. 2011; 29:1252-60.
57. Sikov WM, Berry DA, Perou CM, Singh B, Cirrincione CT, Tolaney SM, Kuzma CS, Pluard TJ, Somlo G, Port ER, Golshan M, Bellon JR, Collyar D, et al. Impact of the addition of carboplatin and/or bevacizumab to neoadjuvant once-per-week paclitaxel followed by dose-dense doxorubicin and cyclophosphamide on pathologic complete response rates in stage II to III triple-negative breast cancer: CALGB 40603 (Alliance). J Clin Oncol. 2015; 33:13-21.

58. von Minckwitz G, Eidtmann H, Rezai M, Fasching PA, Tesch H, Eggemann H, Schrader I, Kittel K, Hanusch C, Kreienberg R, Solbach C, Gerber B, Jackisch C, et al. Neoadjuvant chemotherapy and bevacizumab for HER2negative breast cancer. N Engl J Med. 2012; 366:299-309.

59. Boutsikou E, Kontakiotis T, Zarogoulidis P, Darwiche K, Eleptheriadou E, Porpodis K, Galaktidou G, Sakkas L, Hohenforst-Schmidt W, Tsakiridis K, Karaiskos T, Zarogoulidis K. Docetaxel-carboplatin in combination with erlotinib and/or bevacizumab in patients with non-small cell lung cancer. Onco Targets Ther. 2013; 6:125-34.

60. Herbst RS, O’Neill VJ, Fehrenbacher L, Belani CP, Bonomi PD, Hart L, Melnyk O, Ramies D, Lin M, Sandler A. Phase II study of efficacy and safety of bevacizumab in combination with chemotherapy or erlotinib compared with chemotherapy alone for treatment of recurrent or refractory non small-cell lung cancer. J Clin Oncol. 2007; 25:4743-50.

61. Herbst RS, Ansari R, Bustin F, Flynn P, Hart L, Otterson GA, Vlahovic G, Soh CH, O’Connor P, Hainsworth J. Efficacy of bevacizumab plus erlotinib versus erlotinib alone in advanced non-small-cell lung cancer after failure of standard first-line chemotherapy (BeTa): a double-blind, placebocontrolled, phase 3 trial. Lancet. 2011; 377:1846-54.

62. Johnson DH, Fehrenbacher L, Novotny WF, Herbst RS, Nemunaitis JJ, Jablons DM, Langer CJ, DeVore RF 3rd, Gaudreault J, Damico LA, Holmgren E, Kabbinavar F. Randomized phase II trial comparing bevacizumab plus carboplatin and paclitaxel with carboplatin and paclitaxel alone in previously untreated locally advanced or metastatic non-small-cell lung cancer. J Clin Oncol. 2004; 22:2184-91.

63. Karayama M, Inui N, Fujisawa T, Enomoto N, Nakamura Y, Kuroishi S, Yokomura K, Koshimizu N, Sato M, Toyoshima M, Shirai T, Masuda M, Yamada T, et al. Maintenance therapy with pemetrexed and bevacizumab versus pemetrexed monotherapy after induction therapy with carboplatin, pemetrexed, and bevacizumab in patients with advanced non-squamous non small cell lung cancer. Eur J Cancer. 2016; 58:30-7.

64. Mok TS, Hsia TC, Tsai CM, Tsang K, Chang GC, Chang JW, Sirisinha T, Sriuranpong V, Thongprasert S, Chua DT, Moore N, Manegold C. Efficacy of bevacizumab with cisplatin and gemcitabine in Asian patients with advanced or recurrent non-squamous non-small cell lung cancer who have not received prior chemotherapy: a substudy of the Avastin in Lung trial. Asia Pac J Clin Oncol. 2011; 7:4-12. 
65. Niho S, Kunitoh H, Nokihara H, Horai T, Ichinose Y, Hida T, Yamamoto N, Kawahara M, Shinkai T, Nakagawa K, Matsui K, Negoro S, Yokoyama A, et al. Randomized phase II study of first-line carboplatin-paclitaxel with or without bevacizumab in Japanese patients with advanced non-squamous non-small-cell lung cancer. Lung Cancer. 2012; 76:362-7.

66. Pujol JL, Lavole A, Quoix E, Molinier O, Souquet PJ, Barlesi F, Le Caer H, Moro-Sibilot D, Fournel P, Oster JP, Chatellain P, Barre P, Jeannin G, et al. Randomized phase II-III study of bevacizumab in combination with chemotherapy in previously untreated extensive small-cell lung cancer: results from the IFCT-0802 trialdagger. Ann Oncol. 2015; 26:908-14.

67. Reck M, von Pawel J, Zatloukal P, Ramlau R, Gorbounova V, Hirsh V, Leighl N, Mezger J, Archer V, Moore N, Manegold C. Phase III trial of cisplatin plus gemcitabine with either placebo or bevacizumab as firstline therapy for nonsquamous non-small-cell lung cancer: AVAil. J Clin Oncol. 2009; 27:1227-34.

68. Sandler A, Gray R, Perry MC, Brahmer J, Schiller JH, Dowlati A, Lilenbaum R, Johnson DH. Paclitaxelcarboplatin alone or with bevacizumab for non-small-cell lung cancer. N Engl J Med. 2006; 355:2542-50.

69. Soria JC, Mark Z, Zatloukal P, Szima B, Albert I, Juhasz E, Pujol JL, Kozielski J, Baker N, Smethurst D, Hei YJ, Ashkenazi A, Stern H, et al. Randomized phase II study of dulanermin in combination with paclitaxel, carboplatin, and bevacizumab in advanced non-small-cell lung cancer. J Clin Oncol. 2011; 29:4442-51.

70. Spigel DR, Townley PM, Waterhouse DM, Fang L, Adiguzel I, Huang JE, Karlin DA, Faoro L, Scappaticci FA, Socinski MA. Randomized phase II study of bevacizumab in combination with chemotherapy in previously untreated extensive-stage small-cell lung cancer: results from the SALUTE trial. J Clin Oncol. 2011; 29:2215-22.

71. Zhou C, Wu YL, Chen G, Liu X, Zhu Y, Lu S, Feng J, He J, Han B, Wang J, Jiang G, Hu C, Zhang H, et al. BEYOND: A Randomized, Double-Blind, Placebo-Controlled, Multicenter, Phase III Study of First-Line Carboplatin/ Paclitaxel Plus Bevacizumab or Placebo in Chinese Patients With Advanced or Recurrent Nonsquamous Non-Small-Cell Lung Cancer. J Clin Oncol. 2015; 33:2197-204.

72. Escudier B, Pluzanska A, Koralewski P, Ravaud A, Bracarda S, Szczylik C, Chevreau C, Filipek M, Melichar B, Bajetta E, Gorbunova V, Bay JO, Bodrogi I, et al. Bevacizumab plus interferon alfa-2a for treatment of metastatic renal cell carcinoma: a randomised, double-blind phase III trial. Lancet. 2007; 370:2103-11.

73. Yang JC, Haworth L, Sherry RM, Hwu P, Schwartzentruber DJ, Topalian SL, Steinberg SM, Chen HX, Rosenberg SA. A randomized trial of bevacizumab, an antivascular endothelial growth factor antibody, for metastatic renal cancer. N Engl J Med. 2003; 349:427-34.

74. Van Cutsem E, Vervenne WL, Bennouna J, Humblet Y, Gill S, Van Laethem JL, Verslype C, Scheithauer W, Shang
A, Cosaert J, Moore MJ. Phase III trial of bevacizumab in combination with gemcitabine and erlotinib in patients with metastatic pancreatic cancer. J Clin Oncol. 2009; 27:2231-7.

75. Burger RA, Brady MF, Bookman MA, Fleming GF, Monk BJ, Huang H, Mannel RS, Homesley HD, Fowler J, Greer BE, Boente M, Birrer MJ, Liang SX, et al. Incorporation of bevacizumab in the primary treatment of ovarian cancer. N Engl J Med. 2011; 365:2473-83.

76. Perren TJ, Swart AM, Pfisterer J, Ledermann JA, PujadeLauraine E, Kristensen G, Carey MS, Beale P, Cervantes A, Kurzeder C, du Bois A, Sehouli J, Kimmig R, et al. A phase 3 trial of bevacizumab in ovarian cancer. N Engl J Med. $2011 ; 365: 2484-96$.

77. Pujade-Lauraine E, Hilpert F, Weber B, Reuss A, Poveda A, Kristensen G, Sorio R, Vergote I, Witteveen P, Bamias A, Pereira D, Wimberger P, Oaknin A, et al. Bevacizumab combined with chemotherapy for platinum-resistant recurrent ovarian cancer: The AURELIA open-label randomized phase III trial. J Clin Oncol. 2014; 32:1302-8.

78. Ohtsu A, Shah MA, Van Cutsem E, Rha SY, Sawaki A, Park SR, Lim HY, Yamada Y, Wu J, Langer B, Starnawski M, Kang YK. Bevacizumab in combination with chemotherapy as first-line therapy in advanced gastric cancer: a randomized, double-blind, placebo-controlled phase III study. J Clin Oncol. 2011; 29:3968-76.

79. Taal W, Oosterkamp HM, Walenkamp AM, Dubbink HJ, Beerepoot LV, Hanse MC, Buter J, Honkoop AH, Boerman D, de Vos FY, Dinjens WN, Enting RH, Taphoorn MJ, et al. Single-agent bevacizumab or lomustine versus a combination of bevacizumab plus lomustine in patients with recurrent glioblastoma (BELOB trial): a randomised controlled phase 2 trial. Lancet Oncol. 2014; 15:943-53.

80. Seymour JF, Pfreundschuh M, Trneny M, Sehn LH, Catalano J, Csinady E, Moore N, Coiffier B, Investigators MS. R-CHOP with or without bevacizumab in patients with previously untreated diffuse large B-cell lymphoma: final MAIN study outcomes. Haematologica. 2014; 99:1343-9.

81. Kim KB, Sosman JA, Fruehauf JP, Linette GP, Markovic SN, McDermott DF, Weber JS, Nguyen H, Cheverton P, Chen D, Peterson AC, Carson WE 3rd, O'Day SJ. BEAM: a randomized phase II study evaluating the activity of bevacizumab in combination with carboplatin plus paclitaxel in patients with previously untreated advanced melanoma. J Clin Oncol. 2012; 30:34-41.

82. Duval S, Tweedie R. Trim and fill: A simple funnel-plotbased method of testing and adjusting for publication bias in meta-analysis. Biometrics. 2000; 56:455-63.

83. Gordon MS, Cunningham D. Managing patients treated with bevacizumab combination therapy. Oncology. 2005; 69:25-33.

84. Izzedine H, Ederhy S, Goldwasser F, Soria JC, Milano G, Cohen A, Khayat D, Spano JP. Management of hypertension in angiogenesis inhibitor-treated patients. Ann Oncol. 2009; 20:807-15. 
85. Ferrara N. Vascular endothelial growth factor: basic science and clinical progress. Endocr Rev. 2004; 25:581-611.

86. Schrijvers BF, Flyvbjerg A, De Vriese AS. The role of vascular endothelial growth factor (VEGF) in renal pathophysiology. Kidney Int. 2004; 65:2003-17.

87. de Graaf JC, Banga JD, Moncada S, Palmer RM, de Groot PG, Sixma JJ. Nitric oxide functions as an inhibitor of platelet adhesion under flow conditions. Circulation. 1992; 85:2284-90.

88. Neagoe PE, Lemieux C, Sirois MG. Vascular endothelial growth factor (VEGF)-A165-induced prostacyclin synthesis requires the activation of VEGF receptor-1 and -2 heterodimer. J Biol Chem. 2005; 280:9904-12.

89. Mourad JJ, des Guetz G, Debbabi H, Levy BI. Blood pressure rise following angiogenesis inhibition by bevacizumab. A crucial role for microcirculation. Ann Oncol. 2008; 19:927-34.

90. Zachary I. Signaling mechanisms mediating vascular protective actions of vascular endothelial growth factor. Am J Physiol Cell Physiol. 2001; 280:C1375-86.

91. Bollee G, Patey N, Cazajous G, Robert C, Goujon JM, Fakhouri F, Bruneval P, Noel LH, Knebelmann B. Thrombotic microangiopathy secondary to VEGF pathway inhibition by sunitinib. Nephrol Dial Transplant. 2009; 24:682-5.

92. Eremina V, Jefferson JA, Kowalewska J, Hochster H, Haas M, Weisstuch J, Richardson C, Kopp JB, Kabir MG, Backx PH, Gerber HP, Ferrara N, Barisoni L, et al. VEGF inhibition and renal thrombotic microangiopathy. $\mathrm{N}$ Engl $\mathrm{J}$ Med. 2008; 358:1129-36.

93. Schips L, Dalpiaz O, Lipsky K, Langner C, Rehak P, Puerstner P, Pummer K, Zigeuner R. Serum levels of vascular endothelial growth factor (VEGF) and endostatin in renal cell carcinoma patients compared to a control group. Eur Urol. 2007; 51:168-73; discussion 174.

94. Meade MO, Richardson WS. Selecting and appraising studies for a systematic review. Ann Intern Med. 1997; 127:531-7.

95. Institute NC. Common Terminology Criteria for Adverse Events v3.0 (CTCAE). Available at: http://safetyprofiler-ctep. nci.nih.gov/CTC/CTC.aspx. 2009; Accessed September 15.

96. Comprehensive Meta-analysis. 2006. Available at www. meta-analysis.com. 2009; Accessed September 1.

97. DerSimonian R, Laird N. Meta-analysis in clinical trials. Control Clin Trials. 1986; 7:177-88. 